\title{
MAHENDRADATTĀ: HER ROLES BASED ON ARCHEOLOGICAL INSCRIPTIONS VIEWED FROM FEMINISM APPROACH
}

\author{
Mahendradattā: Peran-Nya dalam Sudut Pandang Arkeologi \\ Feminisme berdasarkan Prasasti
}

\author{
Muhammad Alnoza \\ Program Studi Arkeologi, Fakultas Ilmu Pengetahuan Budaya, Universitas Indonesia \\ Jalan Selo Soemardjan, Kampus UI Depok, Jawa Barat, Indonesia \\ muhamadalnoza@gmail.com
}

Received: 23/01/2020; revision: 09/04-24/04/2020; accepted: 25/04/2020

Published online: $30 / 11 / 2020$

\begin{abstract}
Abstrak
Prasasti merupakan sumber tulisan yang sering dimanfaatkan oleh arkeolog untuk merekontruksi kebudayaan masa lampau. Kajian mengenai prasasti disebut sebagai kajian epigrafi. Periode HinduBuddha merupakan salah satu periode yang menjadi kajian epigrafi. Salah satu pada masa HinduBuddha yang menjadi objek kajian epigrafi dan arkeologi adalah masa Kerajaan Isana di Jawa Timur. Kerajaan tersebut pada abad ke-10 dan ke-11, telah membangun hubungan diplomatik terhadap berbagai kerajaan lain, salah satunya adalah Bali. Mahendradattä sebagai perempuan berkuasa yang hidup dalam pusaran politik Kerajaan Isana (Jawa) merupakan tokoh yang turut membina hubungan diplomatik tersebut melalui pernikahannya dengan Raja Udayana. Prasasti yang ditinggalkan Mahendradattā sebagai seorang penguasa perempuan memunculkan pertanyaan mengenai apa perannya dalam kekuasaan politik antara Jawa dan Bali berdasarkan data prasasti? Metode yang digunakan adalah metode arkeologi. Metode tersebut terdiri dari beberapa tahapan antara lain tahap pengumpulan data, analisis dan interpretasi. Data yang digunakan dalam penelitian ini berupa prasasti, diantaranya Prasasti Pucangan Sansekerta (Jawa), Bwahan A, Batur Pura Abang A, Sading A dan Bebetin A2. Kesemuanya kemudian di analisis melalui deskripsi isi prasasti. Isi prasasti kemudian diinterpretasi dengan landasan teori arkeologi feminisme. Variabel yang digunakan dalam menginterpretasi hasil analisis prasasti adalah identitas gender dan etnisitas dari Mahendradattā.
\end{abstract}

Kata Kunci: bali; feminisme; jawa; mahendradattā; prasasti.

\begin{abstract}
Inscription is a source of writing that is often used by archaeologists to reconstruct past cultures. The study of inscriptions is called epigraphy. The Hindu-Buddhist period is one of the periods in which epigraphy is practiced. The current study is focused on the 10th and 11th centuries Isana Kingdom of East Java. In the 10th and 11th centuries, the kingdom had diplomatic relations with several other kingdoms, one of which was with Bali. Mahendradattā as a powerful woman who lived in the political vortex of the Isana Kingdom (Java) was a figure who helped foster diplomatic relations through marriage to King Udayana. The inscription issued by Mahendradattà begs the question of how powerful this woman was in the context of Javanese and Balinese ties. The method used is the archeological observations, including data collection, analysis and interpretation. The data used in this study include Sanskrit Pucangan Inscriptions (Java), Bwahan A, Batur Pura Abang A, Sading A and Bebetin A2. The contents of the inscription were then interpreted based on feminism approach. The variables employed cover gender and ethnicity of Mahendradattā
\end{abstract}

Keywords: Bali; inscription; feminism; java; mahendradattā.

\section{INTRODUCTION}

The so-called inscription is a text engraved on solid media like stone and metal, recording human activities in the past, including economic, political, religious and 
cultural aspects. The study of inscription is called epigraphy. The task of an epigrapher or epigraphist is to translate an inscription to the modern languages in such a way that the events recorded in it can benefit other parties (Boechari, 1977, pp. 2-5).

Hindu-Buddhist period is an essential part of epigraphy research, Isana Dynasty (Kingdom) in East Java being the focus of this study. Isana was first mentioned in a Sanskrit inscription, Pucangan (1041 AD). Isana dynasty is the heir of the famed Sailendra in Central Java, indicated by $\mathrm{Pu}$ Sindok mentioned as rakryān mapatih $i$ halu and rakryān mapatih $i$ hino in the inscribed texts issued in the period of Rakai Layang Dyah Tlodhong and Rakai Sumba Dyah Wawa. Pu Sindok was a relative of Sailendra, who later rebuilt a kingdom in East Java (Poesponegoro \& Notosusanto, 2010, p. 185).

Isana Dynasty was actively engaging in diplomatic ties with foreign kingdoms, as mentioned in some inscriptions from King Airlangga's reign like the Cane inscription (1021 AD), the Turunhyang A inscription and the Patakan inscription (Soesanti, 2010, p. 6).

Diplomatic ties had been nurtured with other kingdoms across the archipelago long before Airlangga reigned; one worth mentioning is with Bali, as illustrated in the Pucangan inscription. It indicated that Sri Makutawangsawarddhana as the third ruler of Isana fathered a daughter named Mahendradattā, later going into a royal marriage with King Sri Dharmmodayana Warmmadewa of Bali who ruled in 10011011 (Poesponegoro \& Notosusanto, 2010, pp. 323-324).

Mahendradattā was a powerful figure, due to her being a princess and a mother of future kings. It has come as no surprise that, with such a stature, her stories had been written in inscriptions like Pucungan Sanskrit (Java), Bwahan A, Batur Pura Abang A, Sading A and Bebetin AII(Astra, 2002, p. 127).
Mahendradattā has been reported on some previous studies. I Gde Semadi Astra (1997) presented a dissertation entitled Birokrasi pemerintahan Bali Kuno abad XIIXIII: sebuah kajian epigrafis translated The Ancient Bali Administration in the twelfth and thirteenth centuries: an epigraphic approach, presenting a highlight on Warmadewa's reign in Bali. The report highlighted the couple in Bali administration in the tenth century.

Astra (2002) published an article entitled The Supreme Administration in Gunapriyadharmapatni-Dharmodayana

Warmadewa's Reign (Lembaga Pemerintahan tingkat Pusat pada Masa Gunapriyadharmapatni-Dharmodayana Warmadewa), describing the life of Bali under the duo's reign.

Mahendradattā was responsible for the dissemination of Tantrayana teaching across Bali (Surasmi, 2007). Surasmi believed that it had developed all over Java ever since Sindok came to official position, later being extended to Bali by way of Mahendradattā. The evidence of the latter can be traced in the account of Calon Arang and Durga Mahisasuramardhini statue.

The strong and close ties between Bali and Java are also recorded by Saptajaya (2008). Saptajaya provided context for the harmonious tie between the two, dating its origin to Sri Maharaja Sri Wijaya Mahadewi's reign. She was believed to be the first female ruler of Bali of Javanese descent.

Still on the prominent female figure, Mahendradattā was undeniable in introducing literate culture, Javanese characters to the Balinese people (Nastiti, 2017). Nastiti demonstrated that Mahendradattā in her capacity had helped the people to practice the characters.

To the best of my knowledge, there has not been a research particularly taking a closer look at Mahendradattā from a specific attibute. The current study aims to describe her as a socially-constructed figure, either 
from gender approach or cultural aspect. To attain the objective, the inscribed texts on her wisdom are the only resort to hold on to. It is indicated that Mahendradattā was later going into political arena, enabling her to contribute more to the well-being of the eleventh century people of Java and Bali.

To help with the observation, the current study relies on feminism and gender approach, focusing on the androcentric aspect in archeology (Carter, 2010, p. 95). Feminism-approached archeological observations seek to present some new hopes of revisiting female roles in the patriarchal society. It aims to revamp oldfashioned ways of looking at women's positions in the past (Ortner, 2005, pp. 2737).

Women occupy a highly vital role, considered competent in feminism approach, acknowledging their subjectivity. Somewhere down the road, the theory is closely related to gender, resulting in roles separation, inter-roles setting and cultural perspective on gender (Gilrichst, 1991, pp. 495-498). Female roles, furthermore, are continuously related to fast-growing gender construct and other aspects like race and ethnicities (Carter, 2010, p. 99).

Marriage has been considered an institution where human rights of a woman are taken away. It sets woman to be dependent on her partner, making the former inferior due to generally-accepted assumption that she needs protecting. Women are reduced to just taking care of domestic affairs (Thwaites, 2017, pp. 5657).

\section{METHOD}

The current study relies on archeological investigation, the stages of which covering data gathering, analysis and interpretation (Sharer \& Ashmore, 2003, p. 156).

To begin with, information related to Mahendradattā was gathered through literature review, going through some inscriptions on both eleventh century Java and Bali. The texts indicating Mahendradattā were classified and interpreted using feminism approach.

\section{RESULTS AND DISCUSSION}

\section{Inscribed Texts on Mahendradattā}

Sanskrit Pucangan Inscription (Calcutta Stone) (Figure 1). Pucangan, issued by King Airlangga, was recovered in the twentieth century. It was written in two languages: ancient Javanese and ancient Balinese being read and interpreted by different epigraphers. Sanskrit Pucangan famously known as Calcutta stone is now kept at Calcutta Museum, while its counterpart engraved in ancient Java is preserved at the dwelling house of Lord Minto in Scotland (Witasari, 2009). The Pucungan text on Mahendradattā reads:

Inscribed text:

“...śrimmakutavañśavarddhana iti pratīto nrñāmanupamendrah śrís̄annavañśatapanastatāpa

śubhrampratāpena. Tasyādhipasya duhitātimanojňarūpā mūrteva bhāva (?) guṇato yavarājalakșmīh dvīpāntarepi subhagena babhūva pitrā nāmnā krtāa khalu gunapriyadharmmapatnī. Āsīdasāvapo viśiștaviśuddhajanmā

rājāvayādudayanah prathitātprajātah tām śrīmatīvvidhivadeva mahendradattāvvyaktāhvayo

n’̣pasutāmupayacchate smaśreșthah prajāsu sakalāsu kalābhirāmo rāmo yathā

dasārathātsvagunairgarīyānsambhāvit onannatagatirmahas $\bar{a}$ munīndrairerlañgadeva iti divyasutastatobhūt...." (Witasari, 2009).

Translation:

“...Sri

Makutawangsawangsawarddhana is the name of the mighty king, a ruler from Isana Dynasty, and knows no fear. The breathtaking princess, perfect in 


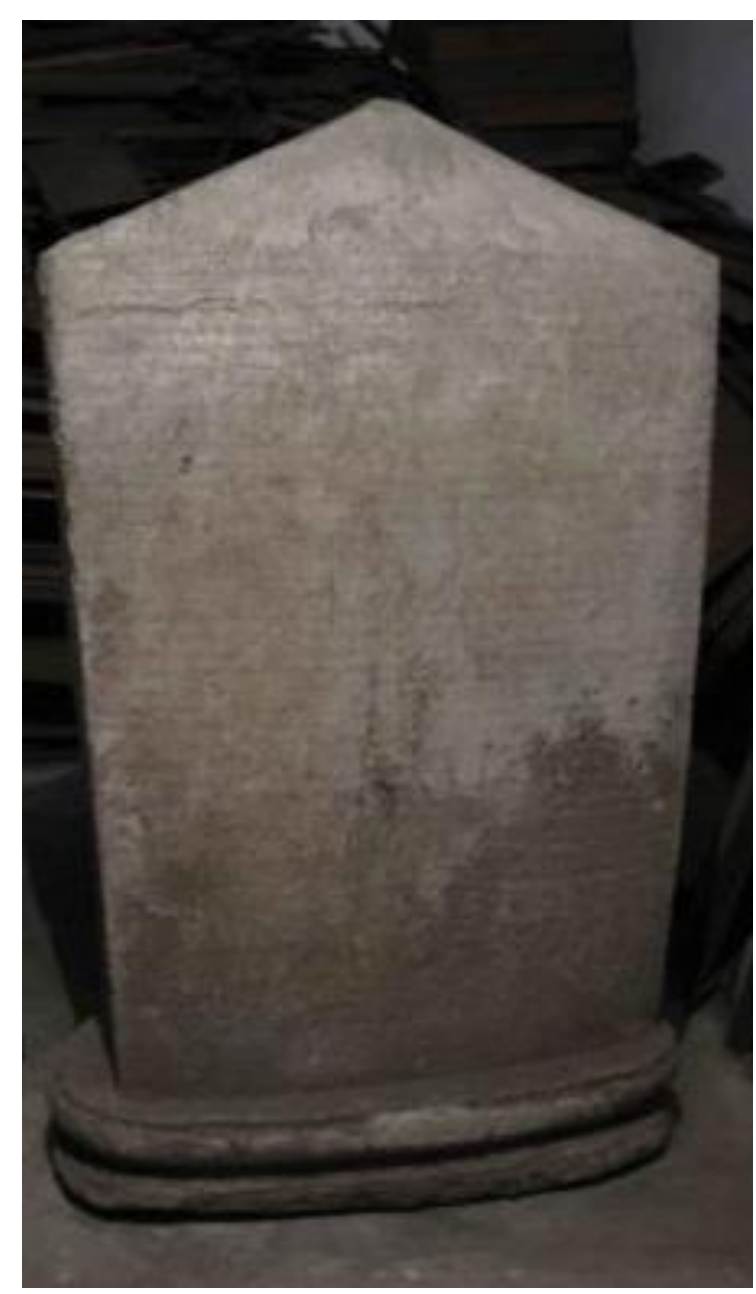

Figure 1. Sanskrit Pucangan Inscriptio (Source: https://koransulindo.com/negeri-medangkerajaan-jawa-pembangun-candi/)

character, seems to reflect on the wellbeing of the Kingdom, later getting another moniker, Gunapriyadharmmapatn $\overline{1}$ (the wise queen). Udayana, a man of royal bloodline from a strong dynasty, gets married to Mahendradatta. The marriage gave birth to an extremely handsome boy named Erlanggadewa, equaling Rama's from Dasaratha and even extends beyond due to his supreme attitudes ......" (Soesanti, 2003).

\section{Bwahan A}

Prasasti Bwahan A is a text engraved on a copper plate (Figure 2). It was written in ancient Javanese. Generally speaking, it is about the separation of Bwahan area from
Desa Kedisan (village), including the taxes levied by Mahendradattā and her husband (Goris, 1954, p. 188).

Inscribed text:

"ing saka 916 phâlgunamâsa . tithi pancami śuklapaksa . pa . ka . wr . marakiḥ wāra. irikā diwaśa nikang karāmān $i$ wingkang raṇu bwahan sáhu lu kāyu. hulu kâyu blas. mwang sādhyanta . panulisan rotangga . rāma kabayān dang ācāryya devvanggi. bhadra. manambah i háji sajalu strī . śri gunapriyadharmmapatnï . sira jalu śrï dharramodâyana warmmadewa. makahetu" (Damais, 1952b, p. 88).

Translation:

"In 916 (Saka Calendar), in Month Phalguna, on the $5^{\text {th }}$ of paro terang, paniron, kaliwon, wrhaspati of Week Marakih, was the day when karaman (village boundary) (?) was on the bank of danau Bwahan, standing under the Forest Keepers, Bias and Sadhyanta, the Poet Rodangga, Si rama kabayan, the Teacher Dewanggi and Bhadra, all of whom were getting prepared to meet Your Majesty Gunapriyadharmapatni and Your Highness Dharmodayana Warmemdewa..." (Goris, 1954, p. 151).

\section{Batur Pura Abang A (Air Hawang)}

Batur Abang is another inscription issued by Udayana himself. It was inscribed in ancient Javanese. It highlighted the complaint filed by people from Air Hawang who felt they were running out of settlement area. (Goris, 1954, p. 188).Inscribed text:

"ing śaka 933 cetramāsa . tithi pratipāda. suklapaksa . ha . pa. śu . wāra mahatal . irikā diwaśa nikang karāman $i$ wingkang ranu air hawang . sapaňambahan hulu kayu. jati karmma - mwang ratmana . maňuralang siwakarta . pamudi ganabrāhma. dewakarmma pramulya . tka ring rāma 


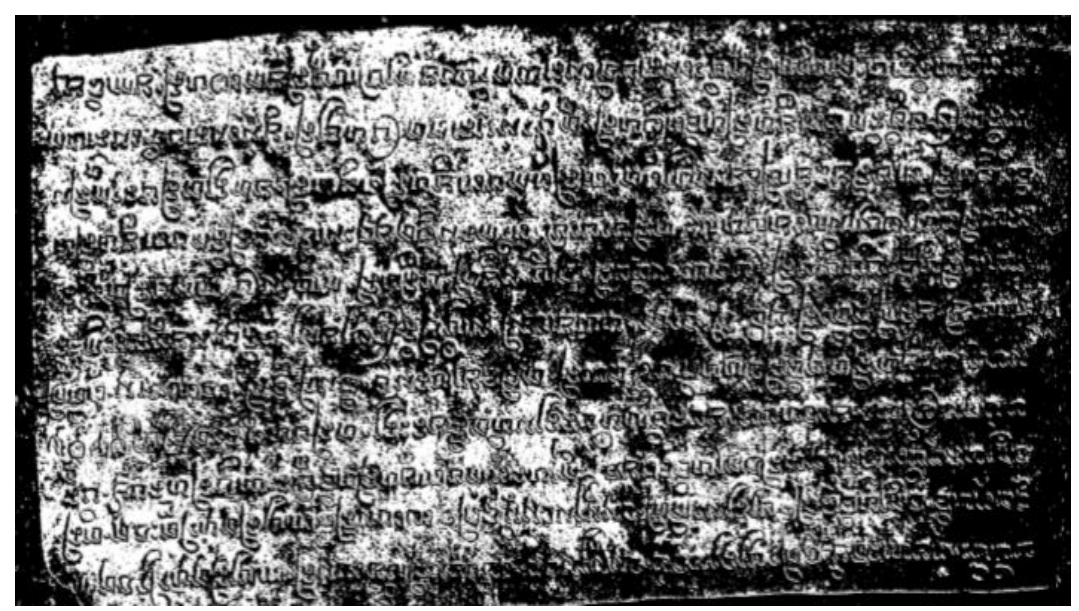

Figure 2. Bwahan A Inscription Plate

(Source: Goris, 1954)

kabayan . rāmendra . suddhaksara . gana iśana . ājn̄āna . widhyâdhipa. suragana . plat . sugya . manambah $i$ pâduka haji śri dharmmodayana warmmadewa . makasopāna rakryān asba . dyah manjak. makahetu mājarakën unaksaya ni hambanya sakarāman. kunang swa sangka ri tan wgïl ya mangisi drbya haji tangkalik . mwang para wulu wulu" (Damais, 1952b, p. 185).

Translation:

"In 933 (Saka Calendar), in Cetra (month), on Day paro terang, haryang, pahing, sukra in Week Mahatal, on a karaman on the bank of a lake: Air Hawang was building a temple: $S i$ Penebang Jatikarma (the cutter) and Ratmana, the writer Siwakarta, Si pamudhi Ganabrahma, dewakarma Pramulya, and many more rama kabayan: Bhamendra, Suddhaksara, Gana igana, Ajnana, Widyadhipa, Suranggana, Plat, Sugya, were all paying homage to Your Majesty. Dharmodayana Warmadewa with the intercession of rakryan on a horse, dyah Manjak, demanded to make it known that the villagers were running out of settlement space. The circumstance was even worse since they were not employed as mangisi drwya haji at a horse ranch and all of wuluwulu..." (Goris, 1954, p. 157).

\section{Sading A (Bantiran)}

Sading inscribed text was written in ancient Balinese (Figure 3). It was about a calling from Bantiran people for a much more secure environment due to the robbers taking peace from those locals. Mahendradattā managed to drive them away (Goris, 1954, p. 188).

Inscribed text:

"Saka 923 wulan jyesțta. krșna daśami - rggas pasar bwijaya pura . tatkālan sang ratu śri gënapriyadharmmapatn̄ . ida maruhani srï dharmmodayana warmmadewa. masuruhang hïntw (?) anak banwa di bantiran maka sahulukayu . alapknan ulih mpungku sogata mahaiśwara . turut da senāpati ser nāyaka di pakirakirān maka supratibaddha . sangka yan lagi tarděngěr di sang ratu . pracāran to banwa di bantiran maka habanwa turut ńoma tuha. maka mārgga di táni tahuna di síla . padá maka patih blěngna. ghya twa yan an ada tamyuña banwa . padā palwasān malasin rumahnna. saka twa mārggaňa. yalapkna ulih mpungku sogata mahaiśwara . turut da senápati ser 

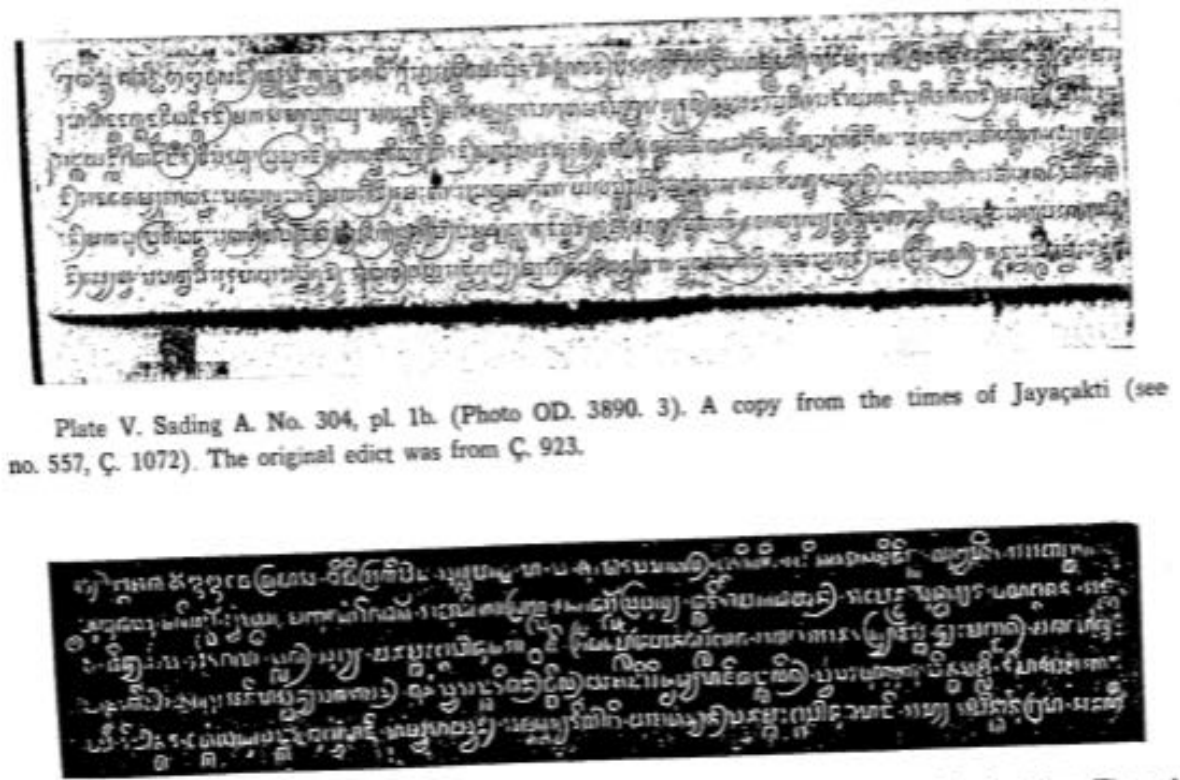

Plate VI. Batur, pura Abang A. No. 305, pl. Th. (Photo CA. 66). Not in the original writing The wri-
ting resembles more that of Anak.Wunggu or Jayaçakti. But in the times of AW. there was no re-edict.
During the reign of Jayaçakti there was quite an other edict cancerning: Kdisan, Bwahan, Er Abang (no. 554).
A later edict about Er Abang is from Jayapangus (na. 605), with quite an other type of writing.

Figure 3. Sading A Inscription Plate (above) and Batur Pura Abang A (below)

(Source: Goris, 1954)

nāyaka di pakirakirān maka supratibaddha . subal tayucap byulik blah gněp pang mwan pangtlu . kunang pwan tani yogya pracāran to banwa ghya twa kramāna . nguniweh tangehangña pakolahin ghya twa. sahā twa pisuruhang ya sarbvva āwan . subal ta ya sarbwa áwa ryyampas ditu di banwaíía . kapwa tamalarib. mapaspasan pada prihawak . kunang pwan manglamwanglamwang . . ." (Damais, 1952b, p. 228).

\section{Translation:}

"In 923 (Saka Calendar), in Jyestha (month), on the $10^{\text {th }}$ of paro gelap, on Day pasaran Wijayapura, when Your Highness Gunapriyadharmapatni and Your Majesty Dharmodayana Warmadewa, demanded that people from Bantiran, stand near the forest, along with Buddha and Siwa priests, and all the rombon: yang mulia senapati (your honor senapati), ser, and nayaka makasupratibaddha meeting J)
Due to an emergency situation at Bantiran, all villagers were urged to stay away from the visitors. They should restrain from foreigners and stay in their houses. It served as a preliminary meeting prior to a court meeting summoned by Shiva and Buddist priests, attended by senapati, ser, nayaka, makasupratibaddha meeting, held three times. The village has been picking themselves up, ever since their properties were robbed from them and those foreigners fled the village" (Goris, 1954, pp. 154-155).

\section{Bebetin AII (Banwa Bharu IB)}

The inscription was inscribed in ancient Balinese. Generally speaking, it was about a demand to build a stronghold at Banua Baru area, written before Udayana and Mahendradattā ascending to power (Goris, 1954, p. 187).

Inscribed text: 
"Punah di śaka 911 wulan posa krșna trayodaśi rggas pasar bwijayakrānla. tatkālan sang ratu luhur śri gunapriyadharmmapatnï . sang ratu maruhani śri dharmmodayana warmmadewa. umanugrahen tu anak banua di banwa bharu . makahakuta jhang . banwa tuha. basta. manuratang tayung. hulu lapu kuňcang . kulapati sādhyagana . me karaksayaňn̆a maghawa. gansur . rahit . ram pa ras para kanakańńa hoka . haňang. tartawan ulih tarahan. mabhariin pangraksayańńa. táni kabakatěn ludan ulih pamwatan . táni kelalanyan . ulih caksu para caksu . me ...." (Damais, 1952b, p. 228).

Translation:

"In the late 911 (Saka Calendar) in Posa (month), on the $13^{\text {th }}$ of krsnapaksa, on Day pasaran Wijayakranta, when Queen (Empress) Gunapriyadharmapatni and King Dharmodayana Warmadewa were handing over some presents to the people from Desa Banwa Bharu, for their efforts in building the stronghold in the company of banwa tuha Basta, Si penulis Tayung, Si hulu lapu Kuncang,Si kulapati Sadhyagana, and all of the officers: Maghawa, Gansur, Rahit. The villagers always went on about their being taken war prisoners. They were then freed from ludan for parwatan, and all the duties to pay for caksu had been relieved of them. In addition, in case of...." (Goris, 1954, p. 147).

\section{Java and Bali in Mahendradattā Administration}

The oldest inscribed texts recovered in Bali are those of yumu pakatahu style. They are found in 7 units, dating their origins to AD 882-914. More units, eight to be exact, of the style with younger dates were later observed, from AD 915-966. The latter had Śri Ugrasena mentioned in the texts, the ruler of Singhamandawa Kingdom (Poesponegoro \& Notosusanto, 2010, p. 309).

Warmadewa is another big-name ruler, aside of Jaya in the history of Balinese Kingdom. It was mentioned in AD 913. It is widely believed that the bearer of the name is Sri Kesariwarmmadewa, noted in Blanjong inscription (AD 914). Blanjong is an inscription released in the reigning period of King Kesariwarmmadewa, the other two being Panempahan and Malatgede. The three inscriptions are labeled Jayastambha. Warmmadewa continued to rule until the reign of King Dharmmotungga Warmmadewa, believed to be family related to Isana Dynasty from Java under the administrative ruling of $\mathrm{Pu}$ Sindok. It reached the super power status with Airlangga sitting on the throne. (Poesponegoro \& Notosusanto, 2010, p. 317).

On paper, the bureaucratic structure in Bali was a bit elaborate as opposed to that in Java, thus making it difficult to be fully studied. On a positive note, some inscribed texts left behind have been of immense help for us to know, at the very least, that a king was aided by a few institutions like panglapuan, samohanda senapati panglapuan, pasamaksa and palapknan. The structure was famously revamped under the reign of King Udayana, with an advisory board called $i$ jro makabehan helping the king rule. The board consisted of some senapati and mpungku (religious leaders) of Buddha-Hindu faith (Poesponegoro \& Notosusanto, 2010, pp. 343-352).

\section{Discussion}

Pucangan is the only Javanesespeaking inscription making a mention of Mahendradattā as well as looking up to her, indicated by long greeting aimed at her as opposed to Airlangga Dynasty members not being mentioned at all. Airlangga, being the reincarnation of Wisnu and the authority issuing the inscription, had given 
Mahendradattā a lot. It is important to notice that the Mahendradattā recorded in Pucangan is taken as an empress not a powerful ruler, but equal in stature as other Airlangga's family members like Makutawangsawangsawarddhana or $\mathrm{Pu}$ Sinḍok.

Mahendradattā, the mother of Airlangga has been differently described from King Udayana, who was merely viewed as a descendant of famous dynasty. Mahendradattā was highly credited, as said in the following:

"The spectacularly beautiful princess, being perfect in character, the manifestation of the whole kingdom's well-being, was handed Gunapriyadharmmapatn $\overline{1}$ to her name by her famous Father, (the wise empress)" (Soesanti, 2003).

Gunapriyadharmmapatn̄i is literally translated to wise empress, with reference to her kind attitude in helping her King with administrative duties. She had her name mentioned several times in Balinese inscriptions.

At this point in time, it is now clear that she was not only superior in political arena, but she was simply the one possessing two major bloodlines running in her veins, granting her diplomatic supremacy in the eleventh century Javanese-Balinese ties.

Mahendradattā ultimately blossomed into a great empress of the King Udayana (Dharmmodayana Warmmadewa), allowing her the authority to issue inscribed texts with her name mentioned alongside Warmadewa; her name always preceded the latter. In light of the common practice by citralekha, superior figure always has her name written first. Damais (1952a) interestingly stated that those texts were ordered by Mahendradattā, and not the King, Udayana.

Special attention being directed to the last-mentioned point, Mahendradattā was undoubtedly getting herself more involved in the royal affairs. Bwahan A indicated her effort in environmental department. Mahendradattā's role as a decision-maker was evident in Bantiran inscription and her military resume, in Bebetin AII.

Mahendradattā's extensive authority had enabled her to contribute massively to Bali. Inscriptions under her order had been even released before Udayana rose to the throne, allowed by gender equality practiced in the kingdom. In regards to female ruler before Udayana, Sri Wijaya Mahadewi was the first woman to do so.

When considering Mahendradattā's political career, one vital observation is that she managed to land a big role in a foreign land while still keeping her home land, Java, in her mind. She was inscribed in Pucangan, on her marriage to Udayana. She became personally united with the king while socially related to Balinese ethnicity being married to their king. All in all, the Empress held two big attributes: Javanese Royal Princess and the Empress of Bali, with clear descriptions of the two. Her role in Java was limited to just being a diplomat, as opposed to her extensive roles in Bali.

The great extent of her roles in Bali is an interesting phenomenon. Never before has an empress had such an extensive authority, not once. No king has allowed his empress to issue an inscribe text or let her bear a king's name. A woman could have only attained such a stature if she had been on the throne sitting as the ultimate ruler, like Sri Wijaya Mahadewi. Mahendradattā is a case where a figure managed to go past the boundary, most likely due to her inherent competence.

The legacy Mahendradattā had left behind was not only ordinary, but it was also a historic one. Mahendradattā taught her people of Tantrayana. So big was her influence that she was enshrined in a statue, Durga Mahisasuramardhini. To preach something so it reached out to the coming generations was not an easy task; 
Kertanegara from Singhasari had to do in a harsher way: invasion. The account of Calon Arang only brought her to a whole other level.

It is crucial to remember that it was not only competence that had catapulted Mahendradattā to the highest level possible, but it was also due to Bali's policy of gender equality, indicated clearly in the ruling of Sri Wijaya Mahadewi; equality that applied to different ethnicities.

\section{CONCLUSION}

Starting as a mere diplomat in the rebuilding of Javanese-Bali ties, Mahendradattā later demonstrated much more extensive authority in the kingdom of Bali. She issued inscriptions, which defied gender obstacles.

There are three conslusions to draw thus far: the royal blood running in her veins had allowed Mahendradattā to record more achievements; her competence helped her to gain extensive authority ; and Bali's policy enabled Mahendradattā to go where she had been.

Mahendradattā's account is an exemplary portrait of how a woman can get involved in political affairs. She is an excellent decision-maker, a pure example that a woman is capable of ruling. Entering marriage institution did not stop her from giving more to the people. At the end of the day, it is not only Airlangga to credit for the Javanese-Balinese ties, Mahendradattā deserves just as much credit.

\section{ACKNOWLEDGEMENT}

The writer is indebted to the Head of Archeology Department of FIB UI, Dr. Ninie Soesanti for her valuable inputs to this article. Credits are due to my fellow students to have made this writing possible.

$$
* * * * * * *
$$

\section{REFERENCES}

Astra, S. I. G. (2002). Lembaga Pemerintahan tingkat Pusat pada Masa GunapriyadharmapatniDharmodayana Warmadewa. Humaniora, 15(27), 127-136. https://doi.org/10.22146/jh.751

Boechari. (1977). Epigrafi dan Sejarah Kuno. Majalah Arkeologi, 1-35.

Carter, Y. (2010). Through a Glass, Darkly: Clouded Perceptions of Feminist and Gender Archaeology. Journal of the Manitoba Anthropology Students' Association, 28, 94-105. https://doi.org/10.1002/oa.1286

Damais, L.-C. (1952a). III. Études d'épigraphie indonésienne. Liste des Principales Inscriptions Datees de L'Indonesie. Tome, 46(1), 1-106. Retrieved from https://www.persee.fr/doc/befeo_0336-1519_1952_num_46_1_5158

Damais, L.-C. (1952b). IV. Études d'épigraphie indonésienne. Discussion de la Date Des Inscriptions. Tome, 46(1), 7-290. Retrieved from https://www.persee.fr/doc/befeo_03361519_1955_num_47_1_5406

Gilrichst, R. (1991). Women's archaeology? Political feminism, gender theory and historical revision. Antiquity, 65, 495-501.

Goris, R. (1954). Prasasti Bali I: Inscripties voor Anak Wuךçu. Bandung: Masa Baru 
Nastiti, S. T. (2017). Perkembangan Aksara Kwadrat di Jawa Tengah, Jawa Timur, dan Bali: Analisis Palaeografi. Forum Arkeologi, 29(3), 175-188. https://doi.org/10.24832/fa.v29i3.94

Ortner, S. B. (2005). Making Gender: The Politics and Erotics of Culture. Retrieved from https://books.google.co.id/books/about/Making_Gender.html?id=XoeDtwMT8zIC\&redir_esc $=\mathrm{y}$

Poesponegoro, M. D., \& Notosusanto, N. (2010). Sejarah Nasional Indonesia: Zaman Kuno. Jakarta: Balai Pustaka.

Saptajaya, I. B. (2008). Pemerintahan Keluarga Warmadewa di Bali serta hubungannya dengan Jawa Timur. In Buku Pusaka Budaya Dan Nilai-nilai Religiusitas (pp. 138-161). Seri Penerbitan Ilmiah Jurusan Arkeologi Fakultas Sastra Universitas Udayana Denpasar.

Sharer, R. J., \& Ashmore, W. (2003). Archaeology:Discovering Our Past. Retrieved from https://books.google.co.id/books?id=pUIrAQAAIAAJ\&q=Archaeology:Discovering+Our+P ast $+2003 \& d q=$ Archaeology:Discovering + Our+Past $+2003 \& h l=i d \& s a=X \& v e d=0 a h U K E w i c v$ OuUibjnAhWc6XMBHRuPA9wQ6AEIKTAA

Soesanti, N. (2003). Airlangga: Raja Pembaharu Jawa. Universitas Indonesia.

Soesanti, N. (2010). Airlangga: His Relation to Kings in South and Southeast Asia. Paradigma: Jurnal Kajian Budaya, 1-14. https://doi.org/10.17510/paradigma.v4i1.155

Surasmi, I. G. A. (2007). Jejak Tantrayana di Bali. Denpasar: Bali Media Adhikarsa.

Thwaites, R. (2017). Making a choice or taking a stand? Choice feminism, political engagement and the contemporary feminist movement. Feminist Theory, 18(1), 55-68. https://doi.org/10.1177\%2F1464700116683657

Witasari, V. H. (2009). Prasasti Pucangan Sansekerta 959 Saka (Suatu Kajian Ulang). Universitas Indonesia. 